\title{
Costs and Income Analysis of Maize Cultivation in Bahraich District of Uttar Pradesh, India
}

\author{
Harendra Pratap Singh Choudhri, G.P. Singh, Rajeev Singh, Punam Kushwaha, \\ Rajeev Kumar* and Ashutosh Kumar Ranjan
}

\author{
Department of Agricultural Economics, N. D. U. A. \& T. Kumarganj Faizabad \\ (U.P.) -224229, India \\ *Corresponding author
}

\section{A B S T R A C T}

\section{Keywords}

Maize, Costs, Income, Farm size, Tabular analysis, Weighted mean

Article Info

Accepted:

10 January 2018

Available Online:

10 February 2018
Study was conducted in Tejwapur block of Bahraich district of U. P. A sample of 100 respondents was chosen through purposive cum proportionate random sampling and were categorised as marginal, small and medium size group of farms. A survey was conducted by personal interview method with use of pre-structured schedule. Simple tabular analysis was done to find out the result. It was found that maize cultivation was profitable at all categories of farm. The total costs of cultivation and gross income per hectare were positively related with size of farms, where as negative trend of net income with farm size should that resources are not efficiently used in maize cultivation at larger size group of farm, technical, managerial and financial problem were noticed as major constraints.

\section{Introduction}

Maize is a one of the most important cereal crop in the world agricultural economy both as food for man and feed for animals. It is a miracle crop having high yield potential. There is no cereal on the earth which has so immense potentiality and that is why it is called 'Queen of Cereals'. Maize is the only cereal which can be grown throughout the year in all three season of kharif, rabi and zaid.

Maize crop is utilized in many ways like other grain crop. Over $85 \%$ of maize produced in the country consumed as human food. Several food dishes including 'Chapattis' are prepared out of maize flour and grains. Green cobs are roasted and eaten by people with great interest. The special variety called 'Popcorn' the grains of which are converted into the popped form which is the favorites food for children in cities. It is also a good source of feed and fodder for cattle, Poultry and piggery. The green fodder can be fed to milch cattle to boost the milk production to a considerable extent; "South African Maize" is a best suited variety for fodder. The crop has to be harvested when the grains are in milky stage, this variety is supposed to have 
Lactogenic effect hence specially suited for milch cattle. The digestibility of maize fodder is higher than sorghum, bajra and other nonleguminous forage crops. Maize plant does not have any problem of poisoning due to hydrocyanic acid, hence if necessary crop can be harvested and fed to cattle at any stage of its growth.

The high carotene content of yellow maize is considered to be very useful in importing yellow colour to egg yok and yellow tinge to the milk. No other concentrate is yet known to substitute maize in this respect.

Maize stand on second place among all the kharif crops after rice, and on third place after rice and wheat among the food grown crops. Seeing the importance of the crop, it seems necessary to study the economics of maize cultivation in order to find the costs involved in its cultivation and profit received from a hectare, the result of the study can guide the framers to allocate the opportunity area of this crop in his crop production plan the study on costs and income analysis was conducted in Bahraich district with following objectives:

To study the different type of costs involve in maize cultivation.

To study the various income measure received from maize cultivation.

To study the major constraints affecting the maize cultivation.

\section{Materials and Methods}

\section{Sampling technique}

Purposive cum random sampling technique was used to select the 100 respondents, from 5 villages of Tejwapur block of Bahraich district. For the further study all selected sample farmers were grouped in three categories of marginal, small and medium. To justify the representation of all category of farmers' proportionate random sampling technique was applied. A sum of 52 marginal, 35 small and 13 medium size of sample farms were studied. Details of sampling are presented in Table 1.

\section{Analytical tools}

The data collected from the sample farmers through personal interview with the help of pre-structured scheduled were analysed and estimated with certain statistical and economical technique like:

\section{Average}

The simplest and important measures of average which have been used into statistical analysis were the simple mean and weighted average. The formula used to estimate the average is:

$\bar{X}=\frac{\sum x}{\mathbb{W}}$,

W.A. $=\frac{\sum \mathrm{W}_{\mathrm{i}} \mathrm{X}_{\mathrm{i}}}{\sum \mathrm{W}_{\mathrm{i}}}$

Where, W. A. = Weighted average, $X_{i}=$ Variable, $W_{i}=$ Weights of $X_{i}$

\section{Cost concepts}

The cost concepts and the items of cost included under this study are given below:

\section{$\operatorname{Cost} \mathrm{A}_{1}$}

This cost approximates and actual expenditure incurred in cash and kind.

Values of hired/owned human, bullock and machinery\& implements laborers 
Value of seed (both farm produced and purchased)

Value of manure (owned and purchased)

Value of insecticides and pesticides and chemical fertilizers

Depreciation on implements and farm buildings

Irrigation charges

Land revenue, assets and other taxes

Interest on working capital

Miscellaneous expenses (artisans, etc.)

Cost $A_{2}$ : Cost $A_{1}+$ rent paid for leased in land

Cost $\mathrm{B}_{1}$ : Cost $\mathrm{A}_{2}+$ interest on value of owned fixed capital assets (Excluding land)

Cost $\mathrm{B}_{2}$ : Cost $\mathrm{B}_{1}+$ rental value of owned land (net land revenue) and rent paid for leased in land.

Cost $\mathrm{C}_{1}$ : Cost $\mathrm{B}_{1}+$ imputed value of family labour

Cost $\mathrm{C}_{2}$ : Cost $\mathrm{B}_{2}+$ imputed value of family labour

Cost $\mathrm{C}_{3}$ : Cost $\mathrm{C}_{2}+10 \%$ of $\mathrm{C}_{2}$ (managerial cost).

\section{Income concepts}

Gross income: Value of farm output (main product and by product) whether sold or utilized by the farm family.

Net income: It is the difference between gross income and total cost, i.e. gross income minus $\operatorname{cost} \mathrm{C}_{1}$ or $\operatorname{Cost} \mathrm{C}_{2}$ or $\operatorname{Cost} \mathrm{C}_{3}$.
Family labour income: Gross income minus $\operatorname{cost} \mathrm{B}_{2}$.

Farm business income: Gross income minus cost $A_{1}$ or cost $A_{2}$ in case of land, leased in farm.

Farm investment income: Net income over cost $\mathrm{C}_{2}$ plus rental value of owned land plus interest on owned fixed capital.

Imputation procedures: Some of the inputs used in the production process come from family sources. The procedures adopted for deriving imputed values are as given under:

Family labour: On the basis of wages paid to attached from servant.

Owned animal labour: On the basis of maintenance which includes the following:

Cost of green and dry fodder

Cost of concentrates

Depreciation on animals and cattle sheds

Labour charges

Other expenses, if any

\section{Results and Discussion}

The result of the presents study as well as relevant discussion has been presented in cost and returns of Maize crop in the study area:

\section{Cost and return}

The cost and return have been summarized in this part on the sample farms. Beside the estimate of total costs, on the basis of six cost concept i.e. Cost $A_{1} / A_{2}$, cost $B_{1}$, cost $B_{2}$, cost $\mathrm{C}_{1}, \mathrm{C}_{2}$ and cost $\mathrm{C}_{3}$, have been worked out for estimation of cost. 
Table.1 Village wise proportionate selection of sample farmers under Different size group of farms

\begin{tabular}{|c|c|c|c|c|c|c|c|c|c|}
\hline \multirow[t]{3}{*}{ SI. No. } & \multirow[t]{3}{*}{ Name of Villages } & \multicolumn{6}{|c|}{ Size of farms } & \multicolumn{2}{|c|}{ Total } \\
\hline & & \multicolumn{2}{|c|}{ Marginal (< 1 ha.) } & \multicolumn{2}{|c|}{ Small (1-2 ha.) } & \multicolumn{2}{|c|}{ Medium (2-4 ha.) } & \multirow[b]{2}{*}{$\mathrm{P}$} & \multirow[b]{2}{*}{$\mathrm{S}$} \\
\hline & & $\mathrm{P}$ & $\mathrm{S}$ & $\mathrm{P}$ & $\mathrm{S}$ & $\mathrm{P}$ & $S$ & & \\
\hline 1. & Maraucha & 45 & 14 & 44 & 13 & 11 & 3 & 100 & 30 \\
\hline 2. & Singhi & 22 & 7 & 13 & 4 & 3 & 1 & 38 & 12 \\
\hline 3. & Raipura & 28 & 9 & 9 & 3 & 2 & 1 & 39 & 13 \\
\hline 4. & Aladadpur & 19 & 6 & 21 & 6 & 9 & 3 & 49 & 15 \\
\hline 5. & Kirtanpur & 52 & 16 & 28 & 9 & 18 & 5 & 98 & 30 \\
\hline Total & & 166 & 52 & 115 & 35 & 43 & 13 & 324 & 100 \\
\hline
\end{tabular}

Note: $\mathrm{P}=$ Population and $\mathrm{S}=$ Sample.

Table.2 Per hectare costs of different inputs used in Maize production (Rs.)

\begin{tabular}{|c|c|c|c|c|c|}
\hline \multirow[t]{2}{*}{ S. No. } & \multirow[t]{2}{*}{ Particulars } & \multicolumn{4}{|c|}{ Size group of farms } \\
\hline & & Marginal & Small & Medium & Overall average \\
\hline 1. & Human Labour & $\begin{array}{c}16786.26 \\
(35.64)\end{array}$ & $\begin{array}{c}15697.08 \\
(31.46)\end{array}$ & $\begin{array}{c}18325.33 \\
(35.89)\end{array}$ & $\begin{array}{c}16605.13 \\
(34.17)\end{array}$ \\
\hline a. & Family Labour & $\begin{array}{c}8189.54 \\
(17.39)\end{array}$ & $\begin{array}{c}2617.63 \\
(5.25)\end{array}$ & $\begin{array}{c}1649.23 \\
(3.23)\end{array}$ & $\begin{array}{l}5389.13 \\
(11.09)\end{array}$ \\
\hline b. & Hired Labour & $\begin{array}{l}8596.72 \\
(18.25)\end{array}$ & $\begin{array}{c}13079.45 \\
(26.22)\end{array}$ & $\begin{array}{c}16676.10 \\
(32.66)\end{array}$ & $\begin{array}{c}11215.99 \\
(23.08)\end{array}$ \\
\hline 2. & Machinery Charges & $\begin{array}{l}8869.23 \\
(18.83)\end{array}$ & $\begin{array}{c}9190.44 \\
(18.42)\end{array}$ & $\begin{array}{l}7729.06 \\
(15.14)\end{array}$ & $\begin{array}{l}8833.43 \\
(18.18)\end{array}$ \\
\hline 3. & Seed & $\begin{array}{c}2549.48 \\
(5.41)\end{array}$ & $\begin{array}{c}3147.95 \\
(6.31)\end{array}$ & $\begin{array}{c}3376.32 \\
(6.61)\end{array}$ & $\begin{array}{c}2866.43 \\
(5.90)\end{array}$ \\
\hline 4. & Manure and fertilizer & $\begin{array}{l}7303.01 \\
(15.51)\end{array}$ & $\begin{array}{l}8661.31 \\
(17.36)\end{array}$ & $\begin{array}{l}7937.17 \\
(15.54)\end{array}$ & $\begin{array}{l}7860.85 \\
(16.18)\end{array}$ \\
\hline 5. & Irrigation & $\begin{array}{c}402.12 \\
(0.86)\end{array}$ & $\begin{array}{l}763.07 \\
(1.53)\end{array}$ & $\begin{array}{c}1273.48 \\
(2.49)\end{array}$ & $\begin{array}{l}641.73 \\
(1.32)\end{array}$ \\
\hline 6. & Plant Protection & $\begin{array}{c}340.98 \\
(0.72)\end{array}$ & $\begin{array}{c}1376.96 \\
(2.76)\end{array}$ & $\begin{array}{c}1339.66 \\
(2.63)\end{array}$ & $\begin{array}{c}883.40 \\
(1.71)\end{array}$ \\
\hline 7. & Total working capital & $\begin{array}{c}28061.54 \\
(59.58)\end{array}$ & $\begin{array}{c}36219.18 \\
(72.60)\end{array}$ & $\begin{array}{c}38331.79 \\
(75.06)\end{array}$ & $\begin{array}{c}32251.85 \\
(66.37)\end{array}$ \\
\hline 8. & Interest on working capital & $\begin{array}{l}187.08 \\
(0.40)\end{array}$ & $\begin{array}{c}241.46 \\
(0.48)\end{array}$ & $\begin{array}{c}255.54 \\
(0.50)\end{array}$ & $\begin{array}{r}215.01 \\
(0.44)\end{array}$ \\
\hline 9. & Rental value of land & $\begin{array}{l}6000.00 \\
(12.74)\end{array}$ & $\begin{array}{c}6000.00 \\
(12.03)\end{array}$ & $\begin{array}{c}6000.00 \\
(11.75)\end{array}$ & $\begin{array}{c}6000.00 \\
(12.35)\end{array}$ \\
\hline 10. & Interest on fixed capital & $\begin{array}{c}377.70 \\
(0.80)\end{array}$ & $\begin{array}{r}277.44 \\
(0.55)\end{array}$ & $\begin{array}{l}187.48 \\
(0.37)\end{array}$ & $\begin{array}{l}317.88 \\
(0.65)\end{array}$ \\
\hline$\overline{11 .}$ & Sub total & $\begin{array}{c}42815.86 \\
(90.91)\end{array}$ & $\begin{array}{c}45355.71 \\
(90.91)\end{array}$ & $\begin{array}{c}46424.04 \\
(90.91)\end{array}$ & $\begin{array}{c}44173.87 \\
(90.91)\end{array}$ \\
\hline 12. & Managerial Cost@10\% of sub-total & $\begin{array}{c}4281.58 \\
(9.09)\end{array}$ & $\begin{array}{c}4535.57 \\
(9.09)\end{array}$ & $\begin{array}{c}4642.40 \\
(9.09)\end{array}$ & $\begin{array}{c}4417.38 \\
(90.09)\end{array}$ \\
\hline & Grand total & $\begin{array}{c}47097.44 \\
(100)\end{array}$ & $\begin{array}{c}49891.28 \\
(100)\end{array}$ & $\begin{array}{c}51066.44 \\
(100)\end{array}$ & $\begin{array}{c}48591.25 \\
(100)\end{array}$ \\
\hline
\end{tabular}


Table.3 Per hectare costs and income measures from maize production on various costs concept (Rs.)

\begin{tabular}{|c|c|c|c|c|c|}
\hline \multirow[t]{2}{*}{ S. No. } & \multirow[t]{2}{*}{ Particulars } & \multicolumn{3}{|c|}{ Size group of farms } & \multirow[t]{2}{*}{ Overall average } \\
\hline & & Marginal & Small & Medium & \\
\hline 1. & Cost A1/A2 & 28248.62 & 36460.64 & 38587.33 & 32466.86 \\
\hline 2. & Cost B1 & 28626.32 & 36738.08 & 38774.81 & 32784.74 \\
\hline 3. & Cost B2 & 34626.32 & 42738.08 & 44774.81 & 38784.74 \\
\hline 4. & Cost $\mathrm{C} 1$ & 36815.86 & 39352.71 & 40424.04 & 38172.82 \\
\hline 5. & Cost C2 & 42815.86 & 45355.71 & 46424.04 & 44173.87 \\
\hline 6. & Cost C3 & 47097.44 & 49891.28 & 51066.44 & 48591.25 \\
\hline 7. & Yield q/ha. & & & & \\
\hline a. & M.P & 42.00 & 43.22 & 43.98 & 42.68 \\
\hline b. & B.P & 72.00 & 71.68 & 72.50 & 71.95 \\
\hline 8. & Grass Income & 60360.00 & 61920.40 & 62974.00 & 61245.96 \\
\hline a. & M.P & 54600.00 & 56186.00 & 57174.00 & 55489.72 \\
\hline b. & B.P & 5760.00 & 5734.40 & 5800.00 & 5756.24 \\
\hline 9. & Net return over cost $\mathrm{C} 3$ & 13262.56 & 12029.12 & 11907.56 & 12654.71 \\
\hline 10. & Family Income & 25733.68 & 19182.32 & 18199.19 & 22461.22 \\
\hline 11. & Farm Business income & 32111.38 & 25459.76 & 24386.67 & 28779.10 \\
\hline 12. & Farm investment income & 23921.84 & 22842.13 & 22737.44 & 23389.97 \\
\hline 13. & Cost of production (Rs./q.) & 1023.60 & 1047.47 & 1054.11 & 1035.92 \\
\hline 14. & \multicolumn{5}{|c|}{ Input-Output ratio } \\
\hline a. & On the basis of cost A1 & $1: 2.13$ & $1: 1.70$ & $1: 1.63$ & $1: 1.88$ \\
\hline b. & On the basis of cost $\mathrm{B} 1$ & $1: 2.10$ & $1: 1.68$ & $1: 1.62$ & $1: 1.86$ \\
\hline c. & On the basis of cost B2 & $1: 1.74$ & $1: 1.45$ & $1: 1.40$ & $1: 1.57$ \\
\hline d. & On the basis of cost $\mathrm{C} 1$ & $1: 1.64$ & $1: 1.57$ & $1: 1.55$ & $1: 1.60$ \\
\hline e. & On the basis of cost $\mathrm{C} 2$ & $1: 1.41$ & $1: 1.36$ & $1: 1.35$ & $1: 1.38$ \\
\hline f. & On the basis of cost $\mathrm{C} 3$ & $1: 1.28$ & $1: 1.24$ & $1: 1.23$ & $1: 1.26$ \\
\hline
\end{tabular}

Similarly, the various measures of farm profits, such as net income, family labour income, farm investment income, farm business income, input-output ratio for maize crop have also been worked out.

The costs and returns generated by maize crop are displayed in Table 2 and 3.

\section{Per hectare costs of cultivation of maize crop}

Per hectare costs incurred on the various input factor in maize production was worked out and are given in Table 2 .

Table 2 indicates that, costs of cultivation of maize was highest on medium farms (Rs.51066.44), followed by small farms (Rs.49891.28) and small farms (Rs.47097.44) respectively. The overall average costs of cultivation was observed (Rs.48591.25) on sample farms.

The major component of the cost were human labour (34.17 per cent), Machinery charge (18.18 per cent), manure and fertilizers (16.18 per cent), rental value of owned land (12.35 percent), seed cost (5.90 per cent), plant protection (1.71 per cent) and irrigation charge (1.32 per cent) respectively of the total costs of cultivation. Per hectare cost of cultivation was found of positive trend with farm size. Costs of plant protection and irrigation were to less because the crop was not affected by insect pest and it was grown in kharif season. The cost increases with an increase in farm size was due to higher expenditure on human labour, seed and irrigation charges on medium size of farms, compared to small and marginal size of farm. 
Per hectare costs and income from the production of maize crop

The Table: 3 revealed that, on an average cost $\mathrm{A}_{1} / \mathrm{A}_{2}, \operatorname{cost} \mathrm{B}_{1}, \operatorname{cost} \mathrm{B}_{2}$, cost $\mathrm{C}_{1}$, cost $\mathrm{C}_{2}$ and cost $\mathrm{C}_{3}$ came to Rs.32466.86, Rs.32784.74, Rs. 38784.74, Rs. 38172.82, Rs.44173.87 and Rs. 48591.25 respectively.

On an average, gross income was recorded Rs. 61245.96 and net income came to Rs.12654.71. On medium farms, gross income was highest, which was recorded Rs.62974.00, followed by small farms Rs. 61920.40 and lowest on marginal farms i.e. Rs.60360.00 respectively.

The net income was highest on marginal farms Rs. 13262.56, followed by small farms Rs. 12029.12 and medium farms Rs. 11907.56. On an average family labour income, farm business income and farm investment income were observed to Rs. 22461.22, Rs. 28779.10 and Rs. 23389.97, respectively. Family labour income was highest on medium farms followed by small and marginal farms \& farm investment income was highest on marginal farms followed by small farm and medium farms and farm business income was highest on marginal farms, followed by small farms and medium farms. On an average, cost of production per quintal and yield per hectare were estimated to Rs. 1035.92 per quintal and 42.68 quintal respective.

On an average input output ratio regarding costs $\mathrm{C}_{3}, \mathrm{C}_{2}, \mathrm{C}_{1}, \mathrm{~B}_{2}, \mathrm{~B}_{1}$, and $\mathrm{A}_{2} / \mathrm{A}_{1}$ were recorded $1: 1.26,1: 1.38,1: 1.60,1: 1.57,1: 1.86$ and $1: 1.88$ respectively. On the basis of $\operatorname{cost} \mathrm{C}_{3}$ input output ratio was highest on marginal farms (1:2.13), followed by small $(1: 1.70)$ and medium $(1: 1.63)$ respectively. It may be concluded the costs of cultivation on different size group of farm increases with an increase in farm size. But net return per hectare was found of negative trend with farm size. It was because of less increase in yield against the increased input factors at increasing size of farm.

\section{References}

Devi, I. S. and Suhasini, K. 2016. "Economics and constraint analysis of non-traditional maize farmers in Mahbubnagar district under tank of Andhra Pradesh." International Research Journal of Agricultural Economics and Statistics; 7(1):86-90.

Murthy, C., Vilas Kulkarni and Kerur, B. P. 2015. Cost and return structure of maize production in North Karnataka. $C A B$ International Research Journal of Agricultural Economics and Statistics; 6(2):364-370.

Navadkar, D. S., Amale, A. J., Gulave, C. M. and Nannaware, V. M. 2012. "Economics of production and marketing of kharif maize in Ahmednagar district of Maharashtra State." CAB Journal article Agricultural Situation in India; 2012. 69(6):309-316.

Rudragouda Chilur; Vasantgouda, R., Shashirekha; Ravindra Yaligar; Nagaraj, D. M., Kanannavar, P. S. and Vijayakumar, P. 2014. "Economic investigation of maize cultivation a state of farmers in Haveri district, Karnataka." CAB Journal article of Environment and Ecology; 32(4):1338-1341.

Satpal Baloda; Gurnam Singh; Sandeep Antil; Naresh Sangwan and Rinwa, R. S. 2007. "Comparative economics of paddy and maize cultivation in Shivalik foothills of Haryana." CAB Journal Article Annals of Biology; 23(1):29-31

Uday, J. P. S., Chandrakar, M. R. and Rahul Harinkhare 2015. "An economic analysis of maize production in Koriya district of Chhattisgarh." CAB Journal article of Trends in Biosciences; 8(2):376- 379.

\section{How to cite this article:}

Harendra Pratap Singh Choudhri, G.P. Singh, Rajeev Singh, Punam Kushwaha, Rajeev Kumar and Ashutosh Kumar Ranjan. 2018. Costs and Income Analysis of Maize Cultivation in Bahraich District of Uttar Pradesh. Int.J.Curr.Microbiol.App.Sci. 7(02): 1060-1065.

doi: https://doi.org/10.20546/ijcmas.2018.702.131 